\title{
Who Will Speak for the Water and the Wildlife Conservation? Solving the Problems of Sustainable Development through Cause-related Marketing
}

\section{Kto przemówi w obronie ochrony wody i dzikiej przyrody? Rozwiązywanie problemów zrównoważonego rozwoju poprzez marketing}

\author{
Akansha Singh*, Govind Swaroop Pathak* \\ *Department of Management Studies, Indian Institute of Technology \\ (Indian School of Mines), Dhanbad, Jharkhand, India \\ E-mail: akansha.2016dr93@ms.ism.ac.in \\ **Department of Management Studies, Indian Institute of Technology \\ (Indian School of Mines), Dhanbad, Jharkhand, India \\ E-mail: gspathak@iitism.ac.in
}

\begin{abstract}
CRM is adopted by organizations as a viable business strategy to implement sustainability initiatives. The existing literature suggests the variations in the execution style of the CRM campaigns by various organizations. This study proposes Cause-related Marketing (CRM) as one of the novel approaches to combat various issues related to sustainable development. The present study is focused to understand the role of CRM in aiding private sector organizations to address the problems of sustainable development and thus support the 'United Nations Sustainable Development Goals (SDGs)' in an Emerging Economy India. The study attempts to integrate the various areas of focus of the CRM campaigns, the sustainability dimensions focused and the various SDGs supported. Further implications, limitations and future research directions have been discussed.
\end{abstract}

Key words: Sustainable Development Goals (SDGs), sustainability dimensions, triple bottom line, cause-related Marketing, qualitative study, India

\section{Streszczenie}

Marketing CRM jest przyjmowany przez organizacje jako realna strategia biznesowa do wdrażania zrównoważonego rozwoju. Istnieją jednak różnice w stylu realizacji kampanii CRM przez różne organizacje. W niniejszym artkule uznano marketing CRM za jedno z nowatorskich podejść do zrównoważonego rozwoju. Niniejsze badanie koncentruje się na zrozumieniu roli marketingu CRM w pomaganiu organizacjom sektora prywatnego rozwijającej się gospodarki Indii w rozwiązywaniu problemów związanych ze zrównoważonym rozwojem, a tym samym wspieraniu Celów zrównoważonego rozwoju Organizacji Narodów Zjednoczonych (SDG). W badaniu podjęto próbę integracji różnych obszarów zainteresowania kampanii CRM, wymiarów zrównoważonego rozwoju i powiązanych z nimi Celów zrównoważonego rozwoju. Omówiono dalsze implikacje, ograniczenia i przyszłe kierunki badań.

Słowa kluczowe: Cele zrównoważonego rozwoju, wymiary zrównoważonego rozwoju, trojakie podejście marketing CRM, badania jakościowe, Indie 
If we are to be responsible, we must accept the fact that we owe a massive debt to our environment. It won't be settled in a matter of months, and it won't be forgiven us

Russell E. Train (1970)

\section{Introduction}

The Rio Declaration on the Environment and Development (1992) stated, human beings are at the center of concerns for sustainable development. They are entitled to a healthy and productive life in harmony with nature. As these concerns grew among the consumers, the organizations expectations that this concern would certainly influence consumers' behaviour also enhanced (Peattie \& Peattie, 2009). The endemic of Globalization brought with itself the issues such as environmental degradation and climate changes (Pawłowski, 2013; Herrmann, 2004). The evident damage to the environment has encouraged various social institutions, Governments and the consumers to reconsider their ways of production and consumption to achieve sustainable development (Jaca et al., 2018). Organizations have always been considered as one of the major stakeholders responsible for decay in the environment conditions. Therefore, in order to be accepted by the society, organizations need to be more sustainable and responsible (Rosati and Faria, 2019).

The implementation of the arduous 2030 agenda of Sustainable Development has provided a global vision for sustainable future. Jones et al. (2018) suggests that achieving this sustainable future requires the commitments from all the stakeholders of the society, including the Governments and the corporate sector. Moreover, the United Nations has called for the urgent need of the contributions from the private sector organizations towards achieving the Sustainable Development Goals (SDGs hereafter) (UNCTAD, 2017). Organizations are called to play a positive role to a more sustainable development (Kolk and Tulder, 2010). The UNCTAD report (2017) suggested that organizations ought to adopt various innovative business approaches focused more closely towards the social and the environmental aspects for achieving these goals. According to Sharma (2002), another area of research that has been given less attention by extant organizational and natural environment research relates to lesser developed countries and development issues. These include the unique processes of organizational change and problems of firms in lesser developed countries, as well as understanding and resolving the complexity of multilevel global interconnectedness of organizational and environmental issues with multiple governance issues (p. 6).

Birkin et al. (2009) pointed towards the need for the development of new and innovative business models for sustainable development. Similarly, Asharfi et al. (2018) opine that organizations should contribute in sustainable development by developing such business models that cover economic, social and environment perspectives. According to Sharma and Hart (2014), the world faces major sustainability challenges that need the collective brainpower of business research and pedagogy for solutions that generate corporate performance on the bottom line (p. 6). Similar to the other activities of the organizations, marketing plays a potential role towards solving environmental problems and achieve sustainable development (Polonsky et al, 1997). In this regard, the present study attempts to propose cause-related marketing (CRM) as an innovative business approach towards achieving the SDGs in an emerging economy. CRM is considered to be one of the novel ways of communicating corporate social responsibility (CSR). The studies related to sustainable development and CSR have been slowly now recognized as a relevant field of study in various prominent management journals (Kolk and Tulder, 2010). Various authors draw our attention towards the scant literature on marketing with a social dimension in emerging markets and call for more research in this direction to advance the field (Nkamnebe, 2011). In addition, Kolandai-Matchett (2009) argue, further research that focus on effective framing of related messages would be instrumental in aiding progress towards sustainability. Moreover, researchers such as Burgees and Steenkamp (2006) point out that marketing theory have limited applicability in embedded emerging market context and have stressed the need for further research in the emerging market context. In view of the above discussion and call for research in this direction, the authors of the present study have considered the cases of three private sector organizations operating in an emerging economy India. Discussing the CRM initiative adopted by the select organizations, the authors attempt to establish the role of CRM in aiding organizations to contribute towards the achievement of SDGs in India. The paper is outlined as: firstly, the paper outlines the literature review related to sustainable development, sustainability and cause-related marketing establishing the theoretical background of the present study. The next section details the methodology adopted followed by the findings and discussion. Further, after considering the conclusions, limitation and future research directions of the study are provided.

\section{Literature review}

This section describes the theoretical background of the study, discussing the Sustainable Development Goals, the sustainability dimensions, the role of private sector organizations and the concept of causerelated marketing.

The Sustainable Development Goals (SDGs) The arduous Sustainable Development Goals (SDGs) were adopted by all the nations at the 2012 
Rio+20 summit. Since then, the Open Working Group (OWG), which was formed to look after the activities to achieve the SDGs comprised of certain business organizations as well, has underwent a lot of groundwork. As an outcome, the Sustainable Development Solutions Network (SDSN) has been set up to mobilize activities from the various sections in solving the problems of sustainable development at local, national, and global context (Gaffney, 2014). The SDGs are the global goals intended with the philosophy that no- one/no-country should be left behind in the path of progress. All the nations are equally responsible for contributing towards the attainment of the global vision. Though these goals are alike for different nations but while implementing them, different degree of attention is targeted to different countries, based on where the specific country stands in relation to the resources and the responsibilities. The threats related to the water scarcity, global warming, river pollution, deforestation etc. have demanded the urgent implementation of the SDGs (Sachs, 2012). In addition, these factors have encouraged the policy makers to adapt sustainable development approach (Pawłowski, 2008). These are also known as Post-2015 or 2030 Development Agenda that suggests the need to work towards the societal and environmental paradigms along with economic development. The 17 Sustainable Development Goals comprise of 169 targets that relate to poverty eradication, addressing issues of gender equality, improving health and education, enhancing communities and tackling urgent challenges such as climate change (United Nations, 2015). Achievement of these potential targets of the SDGs require the committed efforts of all sections of the society including Government, Non-Government Organizations (NGOs), private sector organizations and individuals (Bebbington and Unerman, 2018; Ali et al., 2018).

The present study closely looks towards the role of one of the section of the society viz. private sector organizations towards SDGs. The next section discusses the role of business organizations and various sustainability approaches adopted by them towards SDGs.

\section{Private Sector Organizations and the Sustainable Development}

The United Nations Sustainable Development Goals provide a myriad of opportunities for the private sector organizations to strategically engage and contribute towards the society. According to a report published by Price Waterhouse Coopers (2015), SDGs act as a catalyst to drive growth in an organization. Due to such opportunities for businesses, research on SDGs has recently gained momentum in various related disciplines such as business and management (Bebbington and Unerman, 2018). Organizations adopt strategies that are congruent with the country specific social needs along with the ambitions of the
Government. Various authors have stressed on the necessity of research in the field of sustainability and sustainable development. However, there exist limited empirical evidence on organization's involvement with the SDGs, with only single study conducted by Price Waterhouse Coopers (2015) that has analyzed the role of business organizations in supporting the SDGs (Bebbington and Unerman, 2018). The present study attempts to extend the existing literature and contribute by emphasizing the role of Organizations' cause-related marketing efforts in order to aid them to achieve sustainable development and sustainability, while supporting the SDGs. The concept of cause-related marketing is discussed further.

\section{Cause-related Marketing}

The existing challenges of organizations growth and survival, necessitates the emergence of the concept of sustainability. The concept provides many advantages to the organizations including advancement in performance, risk minimization and enhanced market opportunities (Peloza et al., 2012). Researchers consider CSR as a necessary communication tool for organizations to implement sustainability initiatives and establish their presence in the society (Vanhamme et al., 2012). One of the novel forms of conducting CSR is cause-related marketing (CRM) (Sheikh and Beise-Zee, 2013). It is defined as the process of formulating and implementing marketing activities that are characterized by an offer from the firm to contribute a specified amount to a designated cause when customers engage in revenue-providing exchanges that satisfy organizational and individual objectives (Varadarajan and Menon. 1988, p. 61). Authors such as Bloom et al. (2006) argue that an effectively framed CRM campaign has the potential to generate positive consumer judgement, influences their attitude and purchase intention (KoschateFischer et al., 2012) as well affect their choice (Barone et al., 2000). With CRM, organizations form alliances with non-profit causes or NGOs to generate funds to support the social causes along with accomplishing the goals of the organizations.

The concept of CRM can be related with the three sustainability dimensions (Economic, Social and Environmental). Through CRM, organizations contributes towards the society a part of their revenue generated by associating with a cause. Thus supporting the social dimension of the sustainability. Secondly, organizations employ CRM campaigns to maximize profits along with helping a social cause. This covers the economic dimension of sustainability. Lastly, in forming alliances, organizations may collaborate with a non-profit organization working towards the environmental cause or organizations may directly support an environmental cause. Thus sufficing the environmental dimension of sustainability. Therefore, CRM activities of an organization can be associated with the sustainability dimensions (Christofi et al., 2015). 


\section{Objective of the study}

The above discussion suggests the relationship based on the existence of the sustainability dimension in the concept of CRM. This further the explanation that as like CSR, CRM has the potential to contribute towards the sustainable development. Therefore, the present study attempts to address the following research objective: How are private sector Organizations supporting the SDGs? Moreover, what role does CRM play in enabling organizations to contribute towards the SDGs?

\section{Research methodology}

The methodology adopted for understanding the concept of CRM in relation to its potential to aid organizations in contributing towards the SDGs is further discussed below.

\section{Research Approach Adopted}

The present study adopts the qualitative case study approach to research. Qualitative study allows the researcher to draw rich and profound data from different mediums for analysis (Hewitt-Taylor, 2001). Yin (1989), defined case study as an empirical enquiry that investigate a contemporary phenomenon within its real-life context; when the boundaries between phenomena and context are not clearly evident, and in which multiple sources of evidence are used ( $\mathrm{p}$. 23). Case study is the most widely used method in qualitative study (Yin, 1989; Barnes, 2001).

\section{Case Selection and Sampling Approach Adopted}

According to Seawright and Gerring (2008), the main objective behind selecting a case is that the selected case should provide useful variations in terms of theoretical interest. Therefore, the present study concerns itself with the cause-related marketing campaign of three of the famous fast moving consumer goods (fmcg) companies operating in India. A group of students studying in a reputed institute in India was approached and was asked to mention five FMCG/Consumer Goods Companies they are aware of and whose products they have previously purchased. After taking the responses from the respondents, the authors ranked the companies name in order of their preferences by the respondents. Further, the authors identified the cause-related marketing campaigns conducted by the companies mentioned by them. Later, the authors also consulted two of the faculty members who are experts working in the field of marketing. The opinion of the experts motivated the authors to select three companies and their cause campaigns for the present study. Moreover, the selection was also keeping in view the objective of the study. The authors were inclined to analyze the efforts of the organizations towards the green/environmental causes only. Therefore, purposive sampling technique was best suited for the present study.
Patton (2002) argues that purposeful sampling allows researchers to select information-rich cases to be studied in detail.

\section{Case Summary}

The selected CRM campaign cases are discussed below. The details related to the name of the organization, name of campaign and NGOs (if any) has been depicted in Table 1. In addition, the description about the aim of the campaign is given below.

Table 1. Details of the Selected Cases

\begin{tabular}{|l|l|l|l|}
\hline $\begin{array}{l}\text { S. } \\
\text { No. }\end{array}$ & $\begin{array}{l}\text { Name of } \\
\text { Organization }\end{array}$ & $\begin{array}{l}\text { Name of } \\
\text { Campaign }\end{array}$ & $\begin{array}{l}\text { Associated } \\
\text { NGOs (if any) }\end{array}$ \\
\hline 1. & $\begin{array}{l}\text { Himalaya } \\
\text { Animal } \\
\text { Health Care } \\
\text { Ltd. }\end{array}$ & $\begin{array}{l}\text { Build a } \\
\text { Bond }\end{array}$ & $\begin{array}{l}\text { CUPA (Com- } \\
\text { passion Unlim- } \\
\text { ited Plus Ac- } \\
\text { tion) }\end{array}$ \\
\hline 2. & $\begin{array}{l}\text { Hindustan } \\
\text { Unilever Ltd. }\end{array}$ & $\begin{array}{l}\text { Start a Little } \\
\text { Good (The } \\
\text { Shower) }\end{array}$ & $\begin{array}{l}\text { Hindustan Uni- } \\
\text { lever Founda- } \\
\text { tion (HUF) }\end{array}$ \\
\hline 3. & $\begin{array}{l}\text { Colgate-Pal- } \\
\text { molive India } \\
\text { Ltd. }\end{array}$ & $\begin{array}{l}\text { Make Every } \\
\text { Drop } \\
\text { Count }\end{array}$ & $\begin{array}{l}\text { Water For Peo- } \\
\text { ple- India } \\
\text { Trust }\end{array}$ \\
\hline
\end{tabular}

\section{1) Build a Bond Campaign}

Himalaya Animal Health collaborated with CUPA (Compassion Unlimited Plus Action) to launch its Build a Bond Campaign showing its commitment towards wildlife protection. With this campaign, Himalaya aims to generate sensitivity among individuals towards the animals. It created an app on its Facebook page and urged people to take a pledge for animals. Every pledge taken accounts for contribution of one rupee to CUPA Adoption Centre located in Bangalore (India). This initiative provides opportunity to the consumers to show their commitment and involve themselves directly with the cause. Moreover, Himalaya itself adopted dogs sheltered at CUPA and takes care of their needs.

\section{2) Start a Little Good (The Shower)}

Start A Little Good is an advertisement campaign of HULs commitment towards certain social causes prevailing in India. In the advertisement, a shower booth is set up in the village. A curious villager steps in and turns it on. Seeing the water coming out of it, he starts drinking it to quench his thirst. Soon, many villagers queued to drink water from the shower and fill their baskets. The advertisement highlights the value of water for those deprived of it and the need to conserve it. Speaking about the campaign, a company spokesperson for HUL told, The aim is to raise awareness and prompt action on pressing environmental issues the country (India) is currently facing.

\section{3) Make Every Drop Count}

Colgate-Palmolive (India) collaborated with the METRO Cash \& Carry wholesaler (India) to start the second season of their water conservation programme on March 22, 2019 to mark the World Water Day 2019. The organizations conducted a month 
long Save Water awareness programme (through April 2019) in 27 Metro Cash \& Carry stores across the country. In addition, through this campaign, Colgate pledged a donation of Rs. 10 for every purchase of the select Colgate toothpaste from the 27 stores of Metro Cash \& Carry. The proceeds thus generated were donated to the partnered NGO Water for People for enabling the access of water to communities deprived of it.

\section{Analysis of Data}

The qualitative approach to research was adopted for the analysis of the study. The study aimed at capturing the focus of the campaign concerning (1) the type of cause supported, (2) message appeals and (3) organizations' objective of implementation. The main objective of the authors was to find out whether the campaign has environment sustainability dimension in its implementation. Therefore, the authors adopted the qualitative content analysis method for case study research (Kohlbacher, 2006). The various sources of evidence related to the campaign were collected and analyzed. The iterative coding process of the grounded theory (Strauss and Corbin, 1997) was applied in the present study.

\section{Coding Procedure}

The selected cases were analyzed in depth. Two coders independently coded the data. The codes were formulated and categories were derived after iteratively coding the data. The themes were then related with the existing theory (to attain theoretical sensitivity of the data) as suggested by Glaser and Holton (2004) to generate final coding categories. Firstly, all the 17 SDGs and their targets were analyzed to identify the main SDGs, which are targeted towards the environmental sustainability dimension (categorization done based on Elkington's (1998) three dimensions of sustainability). Secondly, the selected campaigns were analyzed for the type of cause/issue they supported (based on Lafferty and Edmondson, 2014). Table 2 describes the deductive coding scheme adopted for the study. The authors further grouped the causes supported by them and the appeals made in the campaign into the major focus of the campaign promotion. These final cause promoted were related with the sustainability dimension along with the SDG that these organizations attempted to support.

\section{Results}

The key findings generated from the analysis are highlighted in this section. Firstly, the authors analysed all the 17 SDGs and their targets and identified the main goals that are intended to combat the environment related problems in the world (including conservation of natural resources, wildlife protection, climate change etc.). Secondly, the authors dis-
Table 2. Coding Scheme Adopted for the Present Study

\begin{tabular}{|l|l|l|l|}
\hline $\begin{array}{l}\text { S. } \\
\text { No. }\end{array}$ & $\begin{array}{l}\text { Coding } \\
\text { Dimensions }\end{array}$ & $\begin{array}{l}\text { Coding } \\
\text { Categories }\end{array}$ & Reference \\
\hline & $\begin{array}{l}\text { Sustainability } \\
\text { Dimensions } \\
\text { Focused }\end{array}$ & $\begin{array}{l}\text {-Social } \\
\text { Dimension } \\
\text {-Economic } \\
\text { Dimension } \\
\text {-Environment } \\
\text { Dimension }\end{array}$ & $\begin{array}{l}\text { Elkington } \\
(1998)\end{array}$ \\
\hline & $\begin{array}{l}\text { Cause Type/ } \\
\text { Cause } \\
\text { Focused }\end{array}$ & $\begin{array}{l}\text {-Health-related } \\
\text { Causes } \\
\text {-Animal-related } \\
\text { Causes } \\
\text {-Human-related } \\
\text { Causes } \\
\text {-Environment- } \\
\text { related Causes }\end{array}$ & $\begin{array}{l}\text { Lafferty } \\
\text { and Ed- } \\
\text { mondson } \\
\text { (2014) }\end{array}$ \\
& & \multicolumn{2}{|l}{} \\
\hline
\end{tabular}

cussed the various cause supported and message promoted by the CRM campaigns. Lastly, the authors integrated the CRM campaign's focus with the respective SDGs and their targets and formulated an integrated model of CRM supporting the SDGs in an emerging economy. The results are shown up in three tables viz. Table 3, 4 and 5 .

\section{1) SDGs for the Environment}

After analyzing all the 17 SDGs and their respective targets thoroughly, motivated the authors to conclude that all the 17 SDGs are focused towards the three dimensions of sustainability also known as the Triple Bottom Line or 3Ps (Elkington, 1998). The sustainability dimensions include Social Sustainability (People), Economic Sustainability (Profit) and Environmental Sustainability (Planet). As the major focus of the study was towards environment sustainability therefore, in Table 3 the authors present the SDGs and their targets that are directed towards addressing the environment sustainability issues of the world.

\section{2) Focus of the CRM Campaigns}

The select CRM campaign cases were analyzed and coded based on the dimensions and framing components of the campaign suggested in existing CRM literature. The various cause categories used in the framing of the CRM campaign as suggested by Lafferty and Edmondson (2014) were considered to identify the focus area of the selected CRM campaigns. In Table 4, the authors provided the analysis of the three CRM campaigns based on the focus area of the campaign and in which cause category it belonged.

\section{3) Integrating CRM, Sustainability and the SDGs}

In the last phase of the analysis, the researchers attempted to integrate the focus area of the CRM campaigns, sustainability dimension addressed by the CRM campaigns and the SDGs supported by the CRM campaigns. The objective of the researchers was to understand how environment related causes 
Table 3. SDGs focusing towards Water and the Wildlife Conservation

\begin{tabular}{|c|c|c|}
\hline $\begin{array}{l}\text { S. } \\
\text { No. }\end{array}$ & $\begin{array}{l}\text { SDGs Focusing towards the Environ- } \\
\text { mental Sustainability Dimensions }\end{array}$ & Targets \\
\hline 1. & Goal 7: Affordable and Clean Energy & $\begin{array}{l}\text { 7.1: Affordable energy services } \\
\text { 7.5: Upgrade technology }\end{array}$ \\
\hline 2. & $\begin{array}{l}\text { Goal 12: Responsible Consumption and } \\
\text { Production }\end{array}$ & $\begin{array}{l}\text { 12.2: Management and Efficient use of Natural Resources. } \\
\text { 12.8: Disseminating relevant information and make people aware of } \\
\text { sustainable lifestyle in harmony with nature }\end{array}$ \\
\hline 3. & $\begin{array}{l}\text { Goal 13: } \\
\text { Climate Action }\end{array}$ & $\begin{array}{l}\text { 13.2: Integration of measures related climate change into strategies } \\
\text { and policies. } \\
\text { 13.3: Enhance education and raise awareness on climate change miti- } \\
\text { gation and early warnings. }\end{array}$ \\
\hline 4. & $\begin{array}{l}\text { Goal 14: } \\
\text { Life under Water }\end{array}$ & $\begin{array}{l}\text { 14.1: Prevention of all kinds of marine pollution. } \\
\text { 14.3: Minimizing ocean acidification and addressing its impact. }\end{array}$ \\
\hline 5. & $\begin{array}{l}\text { Goal 15: } \\
\text { Life on Land }\end{array}$ & $\begin{array}{l}\text { 15.5: Protection and prevention of endangered species. } \\
\text { 15.7: End poaching and trafficking of protected species. }\end{array}$ \\
\hline
\end{tabular}

Table 4. Describing the cause focused by the campaigns

\begin{tabular}{|l|l|l|l|}
\hline S. No. & Campaign & Cause Focused & Cause Type \\
\hline 1. & HULs Start a Little Good The Shower Campaign & Water Wastage & Environment Cause \\
\hline 2. & Himalaya Build a Bond Campaign & Cruelty Against Animals & Environment Cause \\
\hline 3. & Colgate-Palmolive Make Every Drop Count Campaign & Water Wastage & Environment Cause \\
\hline
\end{tabular}

Table 5. Integrating the CRM Campaigns with the Sustainability Dimensions and Ultimately the SDG Supported

\begin{tabular}{|l|l|l|l|l|}
\hline $\begin{array}{l}\text { S. } \\
\text { No. }\end{array}$ & Campaign Name & Cause Promoted & $\begin{array}{l}\text { Sustainability } \\
\text { Dimension Focused }\end{array}$ & $\begin{array}{l}\text { SDGs } \\
\text { Supported }\end{array}$ \\
\hline 1. & HULs Start a Little Good The Shower Campaign & Water Conservation & Environmental & Goal 12 \\
\hline 2. & Himalaya Build a Bond Campaign & Animal Protection & Environmental & Goal 15 \\
\hline 3. & Colgate-Palmolive Make Every Drop Count Campaign & Water Conservation & Environmental & Goal 12 \\
\hline
\end{tabular}

are being addressed by these business organizations. Therefore, the only dimension considered in the study is environmental dimension. The environmental dimension deals with sustainable business practices by encouraging recycle and reuse, encouraging reduction in energy and water wastage, turning towards green and ecofriendly products, conserving wildlife and habitat. In table 5, the authors depict the integration of all the three concepts (CRM, sustainability and SDGs).

\section{Discussion}

The examination of the marketing strategies and practices with a sustainable development dimension is an area of research that is evolving. Therefore, the researchers and the practitioners require developing a rich understanding of the various ways in which marketing could enable sustainable development. The lack of success experienced by organizations in implementing sustainability initiatives is due to their failure in able to integrate them with their core business strategy (Amini and Bienstock, 2014). The present study has suggested CRM as one such marketing strategy that provides solutions to the problems of sustainable development. Although various authors have suggested that CRM campaigns act as a useful tool in promoting and communicating about a social/environmental cause. However, what remains to be explored is the role that CRM plays in aiding organizations to support the SDGs. In order to address this research question, the present study attempts to integrate the CRM model with the 'United Nations Sustainable Development Goals (SDGs)'. The present study is one of the earlier studies in this direction. Moreover, the issue considered by the authors i.e. water conservation and preservation of the wildlife is of high concern. Marketing seeks to accomplish the needs and wants of the society which have not been previously met in the society (Nkamnebe, 2011). For an increasingly consuming world, if such needs are being met without considering its impact on the environment and sustainability may deprive future generations of certain valuable resources (Nkamnebe, 2011). This situation tasks the marketers to rethink their approaches that be in tune with the Sustainable Development definition which states, development that meets the needs of the present without comprising the ability of future generations to meet their own needs (WCED, 1987, p. 43). Resources should be utilized more efficiently with the aim of fulfilling present needs without compromising future generations (Singh, 2018). The vision for 2030 brought the leaders of the world together to declare, We envisage a world in which every country enjoys sustained, inclusive and sustainable econo- 
mic growth and decent work for all. One in which humanity lives in harmony with nature and in which wildlife and other living species are protected (World Animal Protection, 2015). In this aspect, the present study throws some light on the efforts of the organizations in India towards achieving the Sustainable Development Goals.

The present study addresses issues raised by Hawkins (2015) that how different pressures of engaging and reporting the CSR in different countries/cultures affects the structure of the CRM campaigns. The results of the present study support the notion of counter-topography approach (Hawkins, 2015), which details the differences in the pressures on for-profit organizations for engaging and reporting their CSR differently in different geographical context. As in India, The Company's Act (2013) mandates the organizations to engage in CSR. Following this, many private sector organizations supported the cause of national importance. Expressing his views on the India's water crisis, Amitabh Kant (CEO, NITI Aayog, Government of India) has stated that all stakeholders must come together and business organizations must take water conservation efforts as their top most priority (The Hindustan Times, 2019). Various organizations have implemented similar initiatives in the developed markets as well, related to the cause of conservation, for example, Unilever through its sustainable living plan acts towards biodiversity conservation and Colgate Palmolive contributed over $\$ 400,000$ to support The Nature Conservancy in US. The structure of the CRM campaign differs between both developed and developing markets. The differences are not just based on execution and implementation but also on the novelty of the concept. CRM is a more novel concept in developing markets and its novelty helps the organizations to gain the maximum from such efforts (La Ferle et al., 2013).

Moreover, partnerships are important in achieving the SDGs as Governments, NGOs, intergovernmental organizations (IGOs), and the private sector each bring different strengths to development while facing different challenges. Partnerships recognize the range of activities that affect sustainable development and provide opportunities for the various sectors to pool their assets and thus mitigate individual weaknesses (Hale \& Mauzerall, 2004, p. 223). The researchers opined that partnerships and collaborations are effective for immediate implementation of developmental projects. CRM could be used as a vehicle for developing a partnership between various stakeholders including the NGOs and consumers along with business organizations. Hence, it acts as a win-win to achieve SDGs.

Finally, the present study highlights the role of business organizations in sustainable development. It also shows how through marketing strategy, an organization can tap its latent potential to support the SDGs and solve the problems of the planet. The study also highlights the role of organizations in communicating about the prevailing social causes in the society. They have the potential to be the voices for creating awareness about the conservation of the important natural resources and the habitat.

\section{Implications, limitations and future scope}

The findings of the study has the following implications. Firstly, the study suggests that CRM can be used as an economic-oriented marketing strategy (Varadarajan and Menon, 1988) that enables organizations to be socially oriented at the same time. Secondly, adopting a CRM approach to tackle the problems of the planet would have implications for developing a positive attitude of the individuals towards the organizations. Lastly, enhancing consumer experiences at shopping and engaging them with the campaign motives directly would enable organizations to attract huge socially conscious consumer segment (Grewal et al., 2009). The success of the initiatives undertaken for protecting the environment depend upon the support of all the stakeholders including the people. Therefore, communications of such efforts of the organizations is critical as it influences the choice of the people (Kolandai-Matchett, 2009). The main contribution of the study lies in its effort to provide a practical support on the recommendations provided by Stafford-Smith et al. (2017) for implementing SDGs through multi-stakeholder partnerships.

All studies suffer from certain limitations. Following are the points that may be raised towards the limitations of the present study. Firstly, the authors analysed only three campaigns of three different organizations. Questions may be raised regarding the generalizability of the results in broader context. Secondly, the study has focused only on the FMCG sector as this sector gains more consumer attention. This could be taken as a future research opportunity to analyze the efforts towards sustainability being done by various organizations belonging to different sectors. Thirdly, the limitations of qualitative study applies to the present study as well. Future research is needed to explore consumer responses to various forms of CRM campaigns and their perception regarding the role of organizations in sustainable development. Lastly, the quantitative approaches could be adopted to analyze the dynamics of how do the organizations effort towards sustainability impacts the consumers.

\section{References}

1. AMINI M., BIENSTOCK C. C., 2014, Corporate sustainability: an integrative definition and framework to evaluate corporate practice and guide academic research, in: Journal of Cleaner Production, 76, p. 12-19.

2. ASHRAFI M., ADAMS M., WALKER T. R., MAGNAN G., 2018, How corporate social responsibility can be integrated into corporate sustainability: 
a theoretical review of their relationships, in: International Journal of Sustainable Development \& World Ecology, 25(8), p. 672-682.

3. BARNES D., 2001, Research method for the empirical investigation of the process of formation of operations strategy, in: International Journal of Operations and Production Management, 21(8), p. 10761095.

4. BARONE J.M., MIYAZAKI D.A. TAYLOR A.K., 2000, The influence of cause-related marketing on consumer choice does one good turn deserve another?, in: Journal of the Academy of Marketing Science, 28(2), p.248-262.

5. BIRKIN F., POLESIE T., LEWIS L., 2009, A new business model for sustainable development: an exploratory study using the theory of constraints in Nordic organizations, in: Business Strategy and the Environment, 18(5), p. 277-290.

6. BLOOM N.P., HOEFFLER S., KELLER L.K., MEZA B.E.C., 2006, How social-cause marketing affects consumer perceptions, in: MIT Sloan Management Review, 47(2), p.49-55.

7. BURGESS S. M., STEENKAMP J. B. E., 2006, Marketing renaissance: How research in emerging markets advances marketing science and practice, in: International Journal of Research in Marketing, 23(4), p. 337-356.

8. CHRISTOFI M., LEONIDOU E., VRONTIS D., 2015, Cause-related marketing, product innovation and extraordinary sustainable leadership: the root towards sustainability, in: Global Business and Economics Review, 17(1), p. 93-111.

9. ELKINGTON J., 1998, Partnerships from cannibals with forks: The triple bottom line of 21 st-century business, in: Environmental Quality Management, 8(1), p. 37-51.

10. GAFFNEY O., May 2014, Sustainable Development Goals: Improving Human and Planetary Wellbeing. Global Change, Issue 82. http://www.igbp.net/download/18.62dc35801456272b46d51/1399290813740/ NL82-SDGs.pdf (20.08.2019).

11. GREWAL D., LEVY M., KUMAR V., 2009, Customer experience management in retailing: an organizing framework, in: Journal of Retailing, 85(1), p. 114.

12. HALE T. N., MAUZERALL D. L., 2004, Thinking globally and acting locally: can the Johannesburg partnerships coordinate action on sustainable development?, in: The Journal of Environment \& Development, 13(3), p. 220-239.

13. HAWKINS R., 2015, Shifting conceptualizations of ethical consumption: Cause-related marketing in India and the USA, in: Geoforum, 67, p. 172-181.

14. HERRMANN K. K., 2004, Corporate social responsibility and sustainable development: the European Union initiative as a case study, in: Indiana Journal of Global Legal Studies: 11(2), Article 6.

15. HEWITT-TAYLOR J., 2001, Use of constant comparative analysis in qualitative research, in: Nursing Standard (through 2013), 15(42), p. 39.

16. THE HINDUSTAN TIMES, 2019, India's water crisis: All actors must come together, August 29, p. 8.

17. JACA C., PRIETO-SANDOVAL V., PSOMAS E. L., ORMAZABAL M., 2018, What should consumer organizations do to drive environmental sustainability?, in: Journal of Cleaner Production, 181, p. 201208.
18. JONES P., COMFORT D., HILLIER D., 2018, Common Ground: the sustainable development goals and the marketing and advertising industry, in: Journal of Public Affairs, 18(2), e1619.

19. KOHLBACHER F., 2006, The use of qualitative content analysis in case study research, in: Forum Qualitative Sozialforschung/Forum: Qualitative Social Research, 7(1), p. 1-30.

20. KOLANDAI-MATCHETT K., 2009, Mediated communication of 'sustainable consumption' in the alternative media: a case study exploring a message framing strategy, in: International Journal of Consumer Studies, 33(2), p. 113-125.

21. KOLK A., VAN TULDER R., 2010, International business, corporate social responsibility and sustainable development, in: International Business Review, 19(2), p. 119-125

22. KOSCHATE-FISCHER N., STEFAN I.V. HOYER W.D., 2012, Willingness to pay for cause-related marketing: the impact of donation amount and moderating effects, in: Journal of Marketing Research, 49(6), p.910-927.

23. LA FERLE, C., KUBER, G., EDWARDS, S. M., 2013, Factors impacting responses to cause-related marketing in India and the United States: Novelty, altruistic motives, and company origin, in: Journal of Business Research, 66(3), p. 364-373.

24. LAFFERTY B.A., EDMONDSON D.R., 2014, A note on the role of cause type in cause related marketing, in: Journal of Business Research, 67(7), p. 14551460.

25. NKAMNEBE A. D., 2011, Sustainability marketing in the emerging markets: imperatives, challenges, and agenda setting, in: International Journal of Emerging Markets, 6(3), p. 217-232.

26. PATTON M. Q., 2002, Qualitative research and evaluation methods, Sage, Thousand Oakes.

27. PAWŁOWSKI A., 2008, How many dimensions does sustainable development have?, in: Sustainable Development, 16(2), p. 81-90.

28. PAWŁOWSKI A., 2013, Sustainable Development and Globalization, in: Problemy Ekorozwoju/ problems of Sustainable Development, 8(2), p. 5-16.

29. PEATTIE K., PEATTIE S., PONTING C., 2009, Climate change: a social and commercial marketing communications challenge, in: EuroMed Journal of Business, 4(3), p. 270-286.

30. PELOZA J., LOOCK M., CERRUTI J. MUYOT M., 2012, Sustainability: how stakeholder perceptions differ from corporate reality, in: California Management Review, 55(1), p. 74-97.

31. POLONSKY M. J., CARLSON L., GROVE S., KANGUN N., 1997, International environmental marketing claims: real changes or simple posturing?, in: International Marketing Review, 14(4), p. 218232.

32. ROSATI F., FARIA L. G. D., 2019, Business contribution to the Sustainable Development Agenda: Organizational factors related to early adoption of SDG reporting, in: Corporate Social Responsibility and Environmental Management, 26(3), p. 588-597.

33. SEAWRIGHT J., GERRING J., 2008, Case selection techniques in case study research: A menu of qualitative and quantitative options, in: Political Research Quarterly, 61(2), p. 294-308.

34. SHAH V., August 2018, Top 5 Online Fashion Brands Dominating eCommerce Industry in India, 
https://www.ecomkeeda.com/top-5-online-fashionbrands-dominating-ecommerce-industry-in-india/ (21.08.2019).

35. SHARMA S., HART S. L., 2014, Beyond 'saddle bag' sustainability for business education, in: Organization \& Environment, 27(1), p. 10-15.

36. SHARMA S., 2002, Research in corporate sustainability: What really matters, in: Research in corporate sustainability: The evolving theory and practice of organizations in the natural environment, eds. Sharma S. \& Starik M., Edward Eiger limited: Cheltenham, U.K. and Northampton, M.A., USA, p. $1-29$.

37. SHEIKH S. U. R., BEISE-ZEE R., 2011, Corporate social responsibility or cause-related marketing? The role of cause specificity of CSR, in: Journal of Consumer Marketing, 28(1), p. 27-39.

38. SINGH M., 2018, Equality of Resources, Ethical Principles and Sustainable Development, in: Problemy Ekorozwoju/ Problems of Sustainable Development, 13(2), p. 185-190.

39. STAFFORD-SMITH M., GRIGGS D., GAFFNEY O., ULLAH F., REYERS B., KANIE N., O'CONNELL D., 2017, Integration: the key to implementing the Sustainable Development Goals, in: Sustainability Science, 12(6), p. 911-919.
40. STRAUSS A.,CORBIN J. M., 1997, Grounded theory in practice, Sage, Thousand Oaks.

41. UNCTAD, 2017, New Innovation Approaches to Support the Implementation of Sustainable Development Goals, United Nations, http://unctad.org/ en/PublicationsLibrary/dtlstict2017d4_en.pdf (19.08.2019).

42. VANHAMME J., LINDGREEN A., REAST J., VAN POPERING, N., 2012, To do well by doing good: improving corporate image through cause-related marketing, in: Journal of Business Ethics, 109(3), p. 259274.

43. VARADARAJAN P. R., MENON A., 1988, Causerelated marketing: A coalignment of marketing strategy and corporate philanthropy, in: The Journal of Marketing, 52(3), p. 58-74.

44. WORLD ANIMAL PROTECTION, September 2015, UN incorporate animal protection into 2030 Agenda for Sustainable Development, https:// www.worldanimalprotection.org/news/un-incorporate-animal-protection-2030-agenda-sustainable-development (24.08.2019).

45. WCED, 1987, Our Common Future, Oxford University Press, New York.

46. YIN R.K., 1989, Case Study Research: Design and Methods, Sage, Newbury Park. 
